\title{
DESIGNING AN INTERNSHIP PROGRAM OF AUTHENTIC ENTREPRENEURIAL LEARNING EXPERIENCE FOR STUDENTS IN ENTREPRENEURSHIP CLASS
}

\author{
Inaya Sari Melati $1^{1 *}$, Nina Oktarina ${ }^{1}$, Wisudani Rahmaningtyas ${ }^{1}$, Hana Netti Purasani ${ }^{1}$ \\ ${ }^{1}$ Universitas Negeri Semarang, Indonesia
}

\begin{abstract}
Universities should foster entrepreneurship that requires integration of theory to real-life learning. Internship programs have become popular method active learning which is useful for students to expand their business competencies. This research addresses a unique situation in which a program was created to exclusively assign students to work with entrepreneurs. Using observational diaries as the instrument of a case research methodology, this research tries to measure the effectiveness of an entrepreneurship internship program in providing authentic learning experiences for students of an entrepreneurship class. Authentic learning combined with entrepreneurial internship focuses on serving the learning gaps related to theory of entrepreneurship and its practice. Results indicate that an entrepreneurship internship program successfully expands students' experience of entrepreneurship and increases their intentions to be entrepreneurs. In conclusion, teaching entrepreneurship in university should be tailored to meet real-life practices and should be incorporate the use of flexible entrepreneurial methods, such as coaching and mentoring.
\end{abstract}

Keywords: internship; internship program; entrepreneurship; authentic learning

\section{Introduction}

The number of entrepreneurs in Indonesia has increased dramatically in recent years. In 2013 to 2014 the percentage of entrepreneurs in Indonesia reached only 1.67\%. However, the data from Central Bureau of Statistics (BPS,2017) in 2017 showed that entrepreneurs reach 3.10\% of the total population of 225 million. McClelland's theory (1961) states that to become a developed country, requires $2 \%$ entrepreneurs of the total population of a country. Thus, Indonesia still has opportunity to become a developed country because at this time the number of entrepreneurs is more than $2 \%$.

Nevertheless, this 3.10\% still lags behind Malaysia with 5\% entrepreneurs, China 10\%, Singapore 7\%, Japan $11 \%$ and US 12\% (Puspayoga, 2017). To be able to compete with these countries, Indonesia has to increase the number of entrepreneurs in all parts of the country.

One way to increase the number of entrepreneurs is through education, especially entrepreneurship education. Some research findings suggest that entrepreneurship education is effective in increasing the number of entrepreneurs. Nasr \& Boujelbene (2014) suggest that programs taught by entrepreneurs have a positive influence on entrepreneurial interest and entrepreneurial profile of participants. Din, Anuar, and Usman (2015) found that to increase the effectiveness of entrepreneurship programs required improvement, risk management, locus of control, and self-achievement. This research provides enlightenment to the practice of education at state universities in Malaysia. Entrepreneurship training programs created by the Ministry of Regional Development and Local Government of Malaysia also produce a high average entrepreneurship rate, except for the integrated indicators and low coordination (Ahmad, 2012). 
In fact, although the course of Entrepreneurship has been set to as a compulsory course in universities throughout Indonesia, the effectiveness of this course in creating new entrepreneurs is not optimal. Based on the observation result, most of the students who attended an Entrepreneurship course at State University of Semarang (UNNES) still have low category in some entrepreneurship characteristics formulated by Gasse (2000): entrepreneurial attitude, entrepreneurial project approach, entrepreneurial ability, communication and relationship skills, and good reputation. When several sample participants were interviewed, they revealed that an Entrepreneurship course did not arouse the students' entrepreneur interest. Most lecturers only provide oneway motivation. Some lecturers assign students to make and sell products, but the effect has not been felt by students - the assignments only act as tasks.

Based on these problems, it is necessary to design the teaching of an entrepreneurship course to improve the effectiveness of teaching strategies in higher education. This research will focus on how to design Entrepreneurship lectures so as to provide an authentic learning experiences for students. A learning strategy that will be studied is by applying an entrepreneurial internship program. The purpose of this study is to measure the effectiveness of entrepreneurial internship programs in providing authentic learning experiences so that students experience the process to become entrepreneurs.

\section{Literature Review}

\section{Internship Program}

Internship is a kind of experimental learning where students take the opportunity to apply learned theories from schools in the real world situation, and it provides an opportunity for students to integrate and consolidate thinking and action (Davies, 1990). An Ideal Internship Programs increases many aspects in work performance. Harun et al (2018) stated that the internship program proves to affect the cognitive and psychomotor aspects of students. It enhances students' knowledge, confidence levels, and psychomotor performances that make them have confidence when conducting practice assessments after they finish the program. This is a positive indication at the beginning of the student's work life before coming into real-life work situations.

Furthermore, the graduates of Griffith University in Crebert, et al (2004)'s study recognize the contributions of the university in providing them the program for skill development. They greatly appreciate the internship programs which are very useful for their present work. The importance of teamwork, delegation of responsibilities, and collaborative learning emerged as the most important factor for effective learning.

However, having good impacts to students, internship program can also give negative impacts. There may occur conflicts among students, universities, and industry or institution. Davies (1990) critically pointed out that the three parties view benefits differently, and have different needs, expectations and beliefs. The differences may lead to a concern about 'quality' of a successful internship program that will attract student's choices of future careers. It is still commonly found today that a bad experience in an internship program will actually make students traumatized and tend to avoid the same industry in the future (Fox, 2011). Therefore it takes a good program design so that despite experiencing problems during the internship, students will not experience trauma that exceeds their skill development in the field.

\section{Authentic Entrepreneurial Learning Experience}

Authentic learning typically focuses on real-world, complex problems and their solutions, using role-playing exercises, problem-based activities, case studies, and participation in virtual communities of practice (Lombardi 2007). The learning environments are inherently multidisciplinary. They are "not constructed in order to teach geometry or to teach philosophy. A learning environment is similar to some 'real world' application or 
discipline: managing a city, building a house, flying an airplane, setting a budget, solving a crime, for example (Downes, 2007).”

Reeves, T. C., Herrington, J., \& Oliver, R. (2002) stated that learning researchers have distilled the essence of the authentic learning experience down to 10 design elements, providing educators with a useful checklist that can be adapted to any subject matter domain.

1. Real-world relevance: Authentic activities match the real-world tasks of professionals in practice as nearly as possible. Learning rises to the level of authenticity when it asks students to work actively with abstract concepts, facts, and formulae inside a realistic —and highly social—context mimicking "the ordinary practices of the [disciplinary] culture."

2. Ill-defined problem: Challenges cannot be solved easily by the application of an existing algorithm; instead, authentic activities are relatively undefined and open to multiple interpretations, requiring students to identify for themselves the tasks and subtasks needed to complete the major task.

3. Sustained investigation: Problems cannot be solved in a matter of minutes or even hours. Instead, authentic activities comprise complex tasks to be investigated by students over a sustained period of time, requiring significant investment of time and intellectual resources.

4. Multiple sources and perspectives: Learners are not given a list of resources. Authentic activities provide the opportunity for students to examine the task from a variety of theoretical and practical perspectives, to use a variety of resources, and to require students to distinguish relevance from irrelevant information in the process.

5. Collaboration: Success is not achievable by an individual learner working alone. Authentic activities make collaboration integral to the task, both within the course and in the real world.

6. Reflection (metacognition): Authentic activities enable learners to make choices and reflect on their learning, both individually and as a team or community.

7. Interdisciplinary perspective: Relevance is not confined to a single domain or subject matter specialization. Instead, authentic activities have consequences that extend beyond a particular discipline, encouraging students to adopt diverse roles and think in interdisciplinary terms.

8. Integrated assessment: Assessment is not merely summative in authentic activities but is woven seamlessly into the major task in a manner that reflects real-world evaluation processes.

9. Polished products: Conclusions are not merely exercises or sub steps in preparation for something else. Authentic activities culminate in the creation of a whole product, valuable in its own right.

10. Multiple interpretations and outcomes: Rather than yielding a single correct answer obtained by the application of rules and procedures, authentic activities allow for diverse interpretations and competing solutions.

\section{Theoretical Framework: Teaching Design of Internship Program for Authentic Entrepreneurial Learning Experience}

Based on the previous discussion, internship program can have a positive impact on students who have an entrepreneurship interest, but in some cases it can also cause trauma which make students lose interest to become entrepreneurs. Therefore, it is necessary to design an internship program that is able to minimize unwanted risks during the internship. To design a program that suits the needs of the university, it is necessary to internalize the concept of authentic learning. Implementation of authentic learning is important to provide a 
real entrepreneurial experience for students. That is, students not only learn the theory of entrepreneurship in the classroom, but also plunge directly in the real entrepreneurial environment.

Implementation of internship program in accordance with authentic learning so as to achieve a program concept for authentic entrepreneurial learning experience can be explained as follows:

1. Internship Program has to be real-world relevant: Authentic activities match the real-world tasks of professionals in practice as nearly as possible. The aim of this program is to equip students with entrepreneurial experiences. Prior to running their own business, students need to first observe the activities of actual entrepreneurs. The internship program should be done in small business units where entrepreneurs is still in start-up category. Thus, students can observe and experience the entrepreneurial condition of a start-up industry.

2. Ill-defined problem: Students are required to identify for the tasks and subtasks needed to complete the major task. Students must find their own place of internship in accordance with the criteria set by the lecturer. This is done to train students to think critically and able to define their own place of internship that suits their learning needs.

3. Sustained investigation: Authentic activities comprise complex tasks to be investigated by students over a sustained period of time, requiring significant investment of time and intellectual resources. Internship programs must be done by students in at least 60 days. This time span is considered reasonable and able to measure students' endurance both physically and mentally. During these 60 days they have to fill out an observational diary to record all the information obtained at the internship.

4. Multiple sources and perspectives: Authentic activities provide the opportunity for students to examine the task from a variety of theoretical and practical perspectives, to use a variety of resources, and require students to distinguish relevant from irrelevant information in the process. In the internship program with the concept of authentic learning, students are required to observe situations that occur in the workplace. This requires them to get the widest possible information from various sources so that they can analyze a situation comprehensively and from different points of view.

5. Collaboration: Authentic activities make collaboration integral to the task, both within the course and in the real world. Students are required to work together, not only with their partners, but also with business owners as well as their customers. Students must have excellent interpersonal communication skills to build relationships with people around their premises.

6. Reflection (metacognition): Authentic activities enable learners to make choices and reflect on their learning, both individually and as a team or community. Through observational diary, students write down what they experience during the internship program. This is important as a reflection of what has been done and what is the benefit. It can also be used to formulate answers to questions of how to deal with the same problems in the future.

7. Interdisciplinary perspective: Authentic activities have consequences that extend beyond a particular discipline, encouraging students to adopt diverse roles and thinking in interdisciplinary terms. Interdisciplinary perspective in the internship program is possible to achieve. Students must be able to possess the required skills according to the characteristics of their place of internship. Students who apprentice in a restaurant must be able to cook, and those who apprentice in coffee and bindery, of course, must be able to do the technical tasks. 
Proceeding of the $4^{\text {th }}$ International Conference on Education, Vol. 4, Issue 2, 2018, pp. 34-45

8. Integrated assessment: Assessment is not merely summative in authentic activities but is woven seamlessly into the major task in a manner that reflects real-world evaluation processes. Assessment in the internship program is done in an integrated manner. The lecturer will assess the theoretical abilities of written tests and practical skills by analyzing the content of the observational diary and conducting interviews.

9. Polished products: Authentic activities culminate in the creation of a whole product, valuable in its own right. The brand of new product here is a new insight and persistency from students who have finished their internship program. By following this program, students are expected to have a new perspective on what entrepreneurship is, what it takes to become an entrepreneur, and how to stay in business.

10. Multiple interpretations and outcomes: Authentic activities allow for diverse interpretations and competing solutions. There is no wrong and correct opinion in defining entrepreneurship, how to start, and what strategy to use. All students can define it according to the opinions and knowledge they have gained from the internship program. The output of this program is a prospective entrepreneur who has experienced working in an entrepreneurial place and had a view of how they will build their business. 
Picture 1. The design of internship program for authentic entrepreneurial learning experience

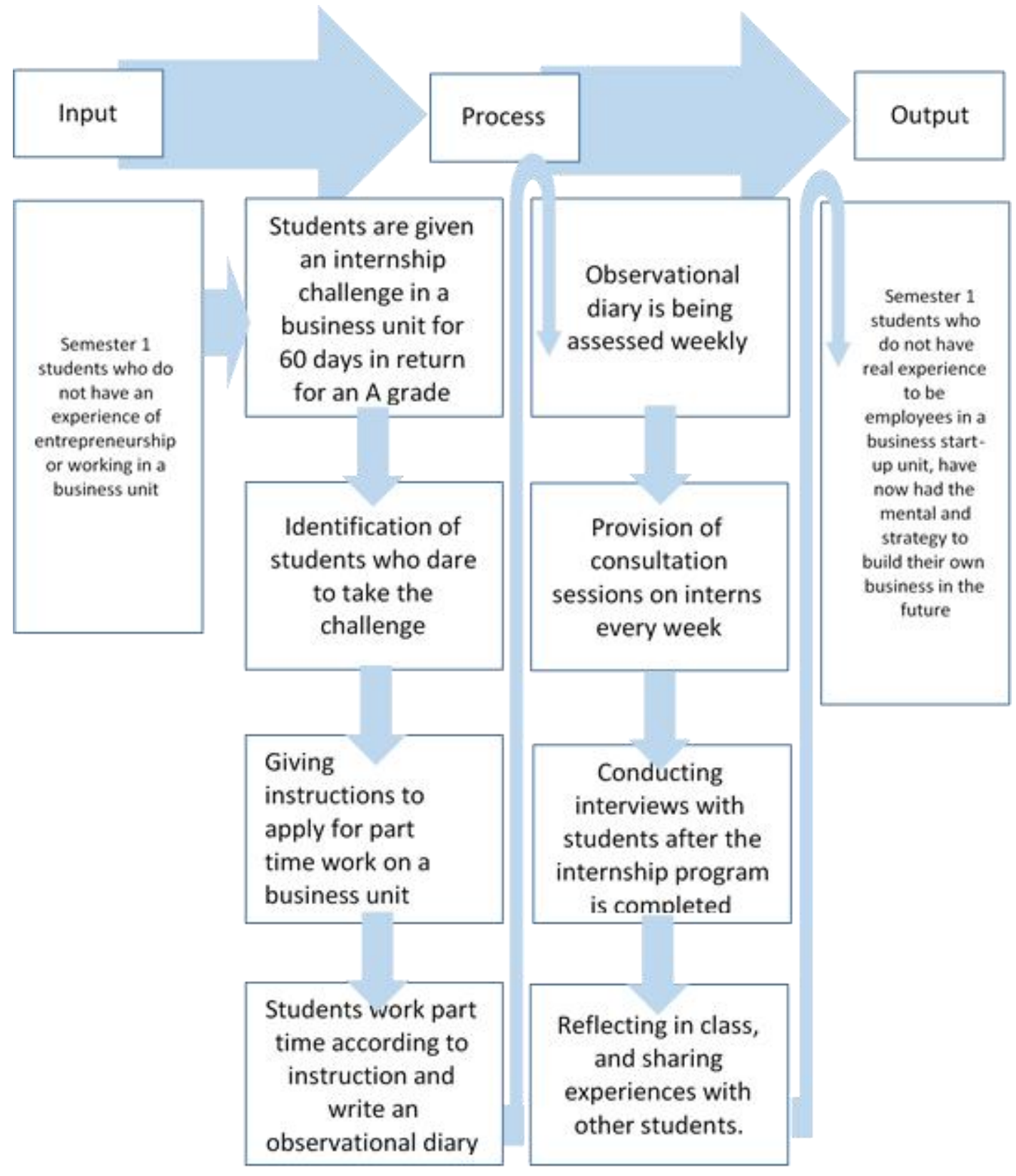

\section{Research Methodology}

This research is a qualitative approach. Data collection was done by observation of class, interview, and observational diary analysis. Measurement of data validity is done by triangulation method. The data are then analyzed with interactive analysis according to Miles and Huberman's model that consists of data collection, data reduction, data presentation, and conclusion (Miles and Huberman in Sutopo, 2002).

The research stages can be described as follows:

1. Lecturers provide challenges in the classroom for students who dare to do an internship in a place of business around the campus.

2. Lecturers give instructions to write an observational diary to detail all the activities undertaken during the internship, what events are encountered, and how they feel during the internship program. 
3. Students undertake the internship program for two months.

4. Lecturers conduct periodic observational diary examination (weekly).

5. After the internship program is completed, the researcher interviews the students who follow the program and analyze the observational diary (using indicator from BEST Report of the European Commission 2012).

6. The researcher does data codification and data reduction.

7. The researcher presents data in a matrix form.

8. The researcher concludes the results of the study.

\section{Results and Discussion}

At the beginning of this research report, there has been presented the amount of students who put an interest in the field of entrepreneurship by providing an open challenge for students to follow an internship program. Of the total 110 students coming from two different classes, namely the study program of economic education and the study program of administrative education, only 11 students were to follow the program. The eleven students consist of 10 students of economic education and 1 student of administrative education. That is, only $9 \%$ of students who have the courage to actually work in a business unit. The eleven students will receive a higher appreciation for their courage at the end of the semester. Each student has set their apprenticeship, consisting of sewing machine shop, photocopy, event organizer, shoe shop, outdoor equipment rental, preschool, car rental, food stalls, snack seller, car salon and outdoor equipment store. In this project, the entrepreneurship program is measured by four indicators, namely: entrepreneurship competence, intention towards entrepreneurship, individual's employability, and society as well as economy.

The data triangulation results from the analysis of observational diaries, observations, and interviews can be observed in Table 1.

Table 1. Matrix of Students' Perception of Authentic Entrepreneurial Learning Experience's Impact to Them

\begin{tabular}{|l|l|l|l|l|}
\hline \multicolumn{5}{|c|}{ Matrix of Students' Perception of Authentic Entrepreneurial Learning Experience 's } \\
Impact to Them
\end{tabular}




\begin{tabular}{|c|c|c|c|c|}
\hline \multicolumn{5}{|c|}{$\begin{array}{c}\text { Table } 1 . \\
\text { Matrix of Students' Perception of Authentic Entrepreneurial Learning Experience 's } \\
\text { Impact to Them }\end{array}$} \\
\hline$\overbrace{\text { Students }}^{\text {Indicators }}$ & $\begin{array}{c}\text { Entrepreneurship } \\
\text { Competence }\end{array}$ & $\begin{array}{l}\text { Intention Towards } \\
\text { Entrepreneurship }\end{array}$ & $\begin{array}{l}\text { Individual's } \\
\text { Employability }\end{array}$ & $\begin{array}{l}\text { Society and } \\
\text { Economy }\end{array}$ \\
\hline Store & business & & & activities \\
\hline $\begin{array}{l}\text { Name: Iva } \\
\text { Internship } \\
\text { Place: } \\
\text { Copy } \\
\text { Center }\end{array}$ & $\begin{array}{l}\text { Intention to get } \\
\text { more experience in } \\
\text { entrepreneurship, } \\
\text { persistent, and } \\
\text { hardworker. }\end{array}$ & $\begin{array}{l}\text { She loves doing } \\
\text { business and she } \\
\text { enjoys the } \\
\text { internship program, } \\
\text { moreover she also } \\
\text { got a big salary for } \\
\text { her job }\end{array}$ & $\begin{array}{l}\text { Eligible. She has } \\
\text { a good managerial } \\
\text { skills and } \\
\text { negotiation skills } \\
\text { because her place } \\
\text { in doing } \\
\text { internship has } \\
\text { trained her very } \\
\text { well }\end{array}$ & $\begin{array}{l}\text { She got many job } \\
\text { opportunity } \\
\text { references from her } \\
\text { seniors, meaning that } \\
\text { she has a good } \\
\text { communication skills }\end{array}$ \\
\hline $\begin{array}{l}\text { Name: } \\
\text { Nisa } \\
\text { Internship } \\
\text { Place: } \\
\text { Event } \\
\text { Organizer }\end{array}$ & $\begin{array}{l}\text { Confident, } \\
\text { responsible, Good } \\
\text { communication } \\
\text { skills, friendly, and } \\
\text { patient }\end{array}$ & $\begin{array}{l}\text { She wants to } \\
\text { provide job } \\
\text { opportunities to } \\
\text { other people and she } \\
\text { has a dream to build } \\
\text { an MLM business }\end{array}$ & $\begin{array}{l}\text { Eligible. She has } \\
\text { good managerial } \\
\text { and promotional } \\
\text { skills in selling } \\
\text { shoes }\end{array}$ & $\begin{array}{l}\text { She could do } \\
\text { negotiation with the } \\
\text { shoe store owner for } \\
\text { the time schedule and } \\
\text { she was able to sell } \\
\text { some couples of } \\
\text { shoes, then she has a } \\
\text { good skills in } \\
\text { communicate }\end{array}$ \\
\hline $\begin{array}{l}\text { Nama: } \\
\text { Selvy } \\
\text { Internship } \\
\text { Place: } \\
\text { Shoes } \\
\text { Store }\end{array}$ & $\begin{array}{l}\text { Responsible, } \\
\text { persistent, and } \\
\text { loyal }\end{array}$ & $\begin{array}{l}\text { She has a big dream } \\
\text { to empower people } \\
\text { around her place at } \\
\text { her village to make } \\
\text { them more } \\
\text { productive by } \\
\text { developing a } \\
\text { business }\end{array}$ & $\begin{array}{l}\text { Eligible. She has } \\
\text { skills and } \\
\text { capability in } \\
\text { engaging well } \\
\text { with her partners } \\
\text { in internship place }\end{array}$ & $\begin{array}{l}\text { She had a good } \\
\text { engagement with her } \\
\text { partners in her job, } \\
\text { meaning that she is } \\
\text { friendly and an easy } \\
\text { going person }\end{array}$ \\
\hline $\begin{array}{l}\text { Nama: } \\
\text { Aditya } \\
\text { Internship } \\
\text { Place: } \\
\text { Rental } \\
\text { Outdoor }\end{array}$ & $\begin{array}{l}\text { Patient, good } \\
\text { communication } \\
\text { skills, and } \\
\text { persistent }\end{array}$ & $\begin{array}{l}\text { She are really } \\
\text { motivated to be an } \\
\text { entrepreneur after } \\
\text { she got salary in her } \\
\text { job }\end{array}$ & $\begin{array}{l}\text { Eligible. Even she } \\
\text { seems do not } \\
\text { comfort with } \\
\text { children for the } \\
\text { first time but she } \\
\text { tried to manage } \\
\text { her emotion well }\end{array}$ & $\begin{array}{l}\text { She learnt to get deal } \\
\text { with children, the } \\
\text { principal, teachers, } \\
\text { and people around } \\
\text { the pre-school }\end{array}$ \\
\hline $\begin{array}{l}\text { Nama: } \\
\text { Rani } \\
\text { Internship } \\
\text { Place: } \\
\text { Pre-School }\end{array}$ & $\begin{array}{l}\text { Intention to get } \\
\text { more experience in } \\
\text { entrepreneurship, } \\
\text { she loves learning } \\
\text { something new }\end{array}$ & $\begin{array}{l}\text { She wants to be a } \\
\text { teacher but she also } \\
\text { wants to have a side } \\
\text { job to be an } \\
\text { entrepreneur. }\end{array}$ & $\begin{array}{l}\text { Eligible. She has } \\
\text { a good managerial } \\
\text { skills in } \\
\text { rescheduling her } \\
\text { activities while } \\
\text { doing internship }\end{array}$ & $\begin{array}{l}\text { She learnt how to } \\
\text { handle customers }\end{array}$ \\
\hline
\end{tabular}




\begin{tabular}{|c|c|c|c|c|}
\hline \multicolumn{5}{|c|}{$\begin{array}{c}\text { Table } 1 . \\
\text { Matrix of Students' Perception of Authentic Entrepreneurial Learning Experience 's } \\
\text { Impact to Them }\end{array}$} \\
\hline$\underbrace{\text { Indicators }}_{\text {Students }}$ & $\begin{array}{l}\text { Entrepreneurship } \\
\text { Competence }\end{array}$ & $\begin{array}{l}\text { Intention Towards } \\
\text { Entrepreneurship }\end{array}$ & $\begin{array}{l}\text { Individual's } \\
\text { Employability }\end{array}$ & $\begin{array}{l}\text { Society and } \\
\text { Economy }\end{array}$ \\
\hline $\begin{array}{l}\text { Nama: } \\
\text { Yutika } \\
\text { Internship } \\
\text { Place: } \\
\text { Car Rental }\end{array}$ & $\begin{array}{l}\text { Discipline, loves to } \\
\text { learn something } \\
\text { new, patient, } \\
\text { responsible }\end{array}$ & $\begin{array}{l}\text { She wants to } \\
\text { provide job } \\
\text { opportunity to other } \\
\text { people around her }\end{array}$ & $\begin{array}{l}\text { Eligible. She has } \\
\text { high intention to } \\
\text { learn something, } \\
\text { here she learnt } \\
\text { how to wrap the } \\
\text { meals, arranging } \\
\text { beverages, etc }\end{array}$ & $\begin{array}{l}\text { She learnt how to } \\
\text { handle customers and } \\
\text { her boss }\end{array}$ \\
\hline $\begin{array}{l}\text { Nama: } \\
\text { Alhazmi } \\
\text { Internship } \\
\text { Place: } \\
\text { Snack } \\
\text { Reseller }\end{array}$ & $\begin{array}{l}\text { Persistent and } \\
\text { patient }\end{array}$ & $\begin{array}{l}\text { He wants to arrange } \\
\text { his own business so } \\
\text { that he can decide } \\
\text { his own rules in } \\
\text { doing business }\end{array}$ & $\begin{array}{l}\text { Eligible. Even } \\
\text { sometimes he got } \\
\text { loss but he tried to } \\
\text { learn from his } \\
\text { error }\end{array}$ & $\begin{array}{l}\text { He had a good } \\
\text { engagement with his } \\
\text { friends }\end{array}$ \\
\hline $\begin{array}{l}\text { Name: Tito } \\
\text { Internship } \\
\text { Place: Car } \\
\text { Wash }\end{array}$ & $\begin{array}{l}\text { Confident and hard } \\
\text { worker }\end{array}$ & $\begin{array}{l}\text { He thinks } \\
\text { competition to get a } \\
\text { job will be more } \\
\text { difficult in the } \\
\text { future so he wants } \\
\text { to create his own } \\
\text { business }\end{array}$ & $\begin{array}{l}\text { Eligible. He has } \\
\text { many experiences } \\
\text { in working } \\
\text { (around } 2 \text { years) }\end{array}$ & $\begin{array}{l}\text { He coukd handle } \\
\text { customer complaint } \\
\text { in a very appropriate } \\
\text { way }\end{array}$ \\
\hline $\begin{array}{l}\text { Name: } \\
\text { Choerul } \\
\text { Internship } \\
\text { place: } \\
\text { Outdoor } \\
\text { Shop }\end{array}$ & $\begin{array}{l}\text { She has a high } \\
\text { spirit to work and } \\
\text { she is a hard } \\
\text { worker }\end{array}$ & $\begin{array}{l}\text { She wants to create } \\
\text { job opportunity to } \\
\text { other people }\end{array}$ & $\begin{array}{l}\text { Eligible. She had } \\
\text { proven that she } \\
\text { could manage her } \\
\text { time well in doing } \\
\text { internship and } \\
\text { studying in } \\
\text { campuss }\end{array}$ & $\begin{array}{l}\text { She had a good } \\
\text { engagement with his } \\
\text { friends }\end{array}$ \\
\hline
\end{tabular}

Based on Table 1, it can be concluded that almost all participants of the internship agree that the program is able to increase personal competence related to the characteristics of an entrepreneur. One of the entrepreneurial competencies trained in the program is discipline. During the program, participants are required to discipline in managing the time so that it can work well without neglecting their duties as a student. Lu'lu'il who performed an internship program at a food stall near the campus wrote in his observational diary:

"... and I do not want to late, so I did not take a shower before going to work. My job is only cooking so it makes me sweat. Therefore it's important to wear make-up ..."

Aditya who worked part-time at an outdoor equipment rental also put forward the same thing. He wrote in his observational diary the following:

"... when I arrived at work I immediately started washing bags, mattresses, tents, tent cover, nesting, and others." 
In addition to discipline, entrepreneurial character that is highly honed in this program is persistency. As written by a student named Iva who worked at a photocopy service as follows:

"Binding ten papers makes me very tired, because I did it extra carefully therefore it takes a long time. It is not easy to bind quickly, so I carefully set the paper and cover, and I often ask my seniors for help.”

Something similar is also experienced by Selvy who apprenticed at a shoe store.

"This one buyer is practically testing my patience for asking some model where the stock is stored in a very difficult location to reach.”

The students' comments are alike with the results of Wendi and Kusumah's (2017) research which states that many of the influences of the factory teaching have a positive and significant effect on the competencies of an entrepreneur. While entrepreneurial competencies according to Osterwalder and Pigneur (2012) are: entrepreneurial factors (the characteristics, attitudes, and behaviors of funders), strategic factors (the effectiveness of firms' strategic decisions and the strategic capabilities of firms) and contextual factors (market dynamics, location-specific advantages).

Furthermore, based on the opinions of participants in this study, it can be concluded that the internship program is able to improve intention towards entrepreneurship. This can be inferred from some statements of participants. One of them is a statement by Nisa who apprenticed at an event organizer. After completing this program, she claimed to be happy and enjoy her work during the program. This can be seen from the writings in the observational diary as follows:

"I have an entrepreneurial desire because I think I can be passionate and carefree to run it."

Aditya also stated the same thing as quoted from the observational diary as follows:

"I want to be an entrepreneur because I want to eradicate the poverty line in my village. I aspire teenagers at my age to be able to work together to build small businesses. "

Tito who did the internship at a Car Wash also expressed his desire to become an entrepreneur:

"If there is a chance, of course I want to be an entrepreneur. I understand if I just rely on diploma, then the competition will be more severe. Even now I start thinking of opening a business. "

These findings are similar to those of Walter and Dohse (2009) which show that entrepreneurship education model that provides work experiences can be used to complement entrepreneurship in different ways.

The next indicator is individual's employability. In line with the results of this study, several previous studies have found the same thing, namely the result internship program as an effective mechanism to improve employability (Shoenfelt, Stone, Kottke, 2012). Lerman (2013) states that the skill-enhancing effects of several youth programs and demonstrations, with an emphasis on how well these efforts raise non-academic skills directly through purposeful activities or indirectly as a result of other employment-enhancing services. The survey results from Gault, Leach, and Duey (2010) indicate significantly more full-time opportunities for undergraduates with internship experience, corroborating earlier published empirical research. Additionally, while even average-performing interns were significantly more likely to receive full-time job offers than noninterns, high-performing interns were more likely to receive higher starting salaries. Finally, the study shows that high intern performance results in enhanced employer-perceived value of the internship program.

The last indicator of Authentic Entrepreneurial Learning Experience is social and economic competence. Internship programs are proven to improve participants' ability in social communication and economic 
intelligence. Mutiara, a student working in a tailor store, wrote that this internship program trains her communication skills and stimulates her to learn something new.

"I talked to the shop owner about the barriers, usually about what I did not know related to sewing tools.

Working in this place got me interested as well for wanting to learn sewing. "

On the other hand, Rani, who did the program in a pre-school, wrote that she initially felt frustrated working in the neighborhood, but then she began to adapt after a few days of work.

"The most uncomfortable work in early childhood is the children who are stubborn and could not be arranged, uugghhh they made me stressed. ... But then on the fourth day of work, I felt very happy, why?? Because I could play with cute children ... Since the eighth day and even until today are the days that I really like. Why? Because they did gymnastics and we were able to go out of the building. "

The findings that the internship program enhances the social and economic capacity of the participants are supported by the results of previous research, namely Kim and Park's (2013) research which implies that desirable social experiences during students 'internship can ultimately lead to a change in students' perceptions. Back and Halim (2006) stated Internal Reports a number of significant learning outcomes of which the most significant were personal and interpersonal skills.

\section{Conclusion}

This empirical investigation focuses on designing an internship program of authentic entrepreneurial learning experience for students in entrepreneurship class. The findings of this research regarding entrepreneurial internship are supporting earlier perception-based researches suggesting interns are better prepared to stimulate students to be entrepreneurs. Result indicates that entrepreneur internship program successfully enhanced students' experience of entrepreneurship and increased their intentions to be entrepreneurs. All the indicators: entrepreneurship competence, intention towards entrepreneurship, individual's employability, and society and economy have been confirmed very well. For suggestion, teaching entrepreneurship in university should be tailored to meet real-life practices and use of flexible entrepreneurial methods, such as coaching and mentoring.

\section{References}

Statistik, B. P. (2017). Kebutuhan Data Ketenagakerjaan Untuk Pembangunan Berkelanjutan.

McClelland, D.C. (1961). The Achieving Society. Princeton, NJ: Van Nostrand.

Puspayoga, A.A.G.N. (2017). Ratio Wirausaha Indonesia Naik Jadi 3,1 Persen. Berita/Siaran Pers. Kementrian Koperasi dan Usaha Kecil dan Menengah Republik Indonesia. Retrieved April 25, 2018 from http://www.depkop.go.id/content/read/ratio-wirausaha-indonesia-naik-jadi-31-persen

Nasr, K. B., \& Boujelbene, Y. (2014). Assessing the impact of entrepreneurship education. Procedia-Social and Behavioral Sciences, 109, 712-715.

Din, B. H., Anuar, A. R., \& Usman, M. (2016). The effectiveness of the entrepreneurship education program in upgrading entrepreneurial skills among public university students. Procedia-Social and Behavioral Sciences, 224, 117-123.

Ahmad, Z.S. (2013). The need for inclusion of entrepreneurship education in Malaysia lower and higher learning institutions. Education+ Training, 55(2), 191-203.

Gasse Y, «L'entrepreneuriat à l'université LAVAL : intérêts, intention, prévalence et besoins des étudiants », En collaboration avec M.Tremblay, Centre d'Entrepreneuriat et de PME, Automne 2002.

Davis, L. "Experience-based Learning within the Curriculum." A synthesis study. CNAA, Sheffield (1990). 
Harun, H., Rahman, A. W. A., Noorazman, A. S., Noor, S. N. F. M., \& Sahak, A. A. M. (2018). The Effectiveness of Cognitive and Psychomotor Domain of Culinary Art Students' Performance after Internship in Private Colleges. In MATEC Web of Conferences (Vol. 150, p. 05021). EDP Sciences.

Crebert*, G., Bates, M., Bell, B., Patrick, C. J., \& Cragnolini, V. (2004). Developing generic skills at university, during work placement and in employment: graduates' perceptions. Higher Education Research \& Development, 23(2), 147-165.

Fox, T. (2001). A sense of place. Caterer and Hotelkeeper, 189 (4160), 30-31.

Lombardi, M. M. (2007). Authentic learning for the 21st century: An overview. Educause learning initiative, 1(2007), 1-12.

Downes, S. (2007). Emerging Technologies for Learning. Coventry, U.K. : Becta, Retrieved April 25, 2018 from http://www.partners.becta.org.uk/pagedocuments/research/emerging technologies07chapter 2.pdf

Reeves, T. C., Herrington, J., \& Oliver, R. (2002). Authentic activities and online learning.

Sutopo, H. B. (2002). Metodologi penelitian kualitatif.

Wendi, H. F., \& Kusumah, I. H. (2018, February). Industrial Internship and Entrepreneurship Competencies on Vocational High School Students. In IOP Conference Series: Materials Science and Engineering (Vol. 306, No. 1, p. 012047). IOP Publishing.

Osterwalder, A and Pigneur, Y. 2012. Business Model Generation. Jakarta: Elex Media Komputindo.

Walter, S. G., \& Dohse, D. (2009). The interplay between entrepreneurship education and regional knowledge potential in forming entrepreneurial intentions (No. 1549). Kiel working paper.

Shoenfelt, E. L., Stone, N. J., \& Kottke, J. L. (2013). Internships: An established mechanism for increasing employability. Industrial and Organizational Psychology, 6(1), 24-27.

Lerman, R. I. (2013). Are employability skills learned in US youth education and training programs?. IZA Journal of Labor Policy, 2(1), 6.

Gault, J., Leach, E., \& Duey, M. (2010). Effects of business internships on job marketability: the employers' perspective. Education+ Training, 52(1), 76-88.

Kim, H. B., \& Park, E. J. (2013). The role of social experience in undergraduates' career perceptions through internships. Journal of Hospitality, Leisure, Sport \& Tourism Education, 12(1), 70-78.

Edward Beck, J., \& Halim, H. (2008). Undergraduate internships in accounting: What and how do Singapore interns learn from experience?. Accounting Education: an international journal, 17(2), 151-172. 